\title{
ВИКЛАДАННЯ КУРСУ ДЕРМАТОЛОГІЇ ТА ВЕНЕРОЛОГІЇ В ОНМЕДУ НА СУЧАСНОМУ ЕТАПІ РОЗВИТКУ ВИЩОЇ МЕДИЧНОЇ ОСВІТИ
}

\author{
В. В. Шухтін, О. О. Шандра, А. І. Гоженко \\ Одеський національний медичний університет, \\ Украӥнський НДІ медицини транспорту, Одеса
}

\section{TEACHING OF DERMATOLOGY AND VENEROLOGY IN ONMU ON MODERN STAGE OF HIGHER MEDICAL EDUCATION DEVELOPMENT}

\author{
V. V. Shukhtin,A.A. Shandra,A. I. Gozhenko \\ Odesa National Medical University, \\ Ukrainian Research Institute for Medicine of Transport, Odesa
}

\begin{abstract}
Забезпечення високого рівня підготовки лікарів $є$ вимогою сьогодення, оскільки цей фах вимагає належних знань $\mathrm{i}$ вмінь для надання належної медичної допомоги населенню. У статті представлені сучасні тенденції розвитку дерматології та венерології, підходи до вдосконалення ії викладання в медичних університетах. Працівники кафедри дерматології та венерології ОНМедУ розповідають, що у викладанні дерматології, як однієї з базових медичних дисциплін, необхідно відновити елемент зацікавленості студентів до навчання цієї науки. Організація навчально-методичної роботи на кафедрі орієнтована на кінцеву мету навчання й професійну лікарську діяльність.
\end{abstract}

Ensuring a high level of training doctors are demanding today, because this profession requires adequate knowledge and skills to provide appropriate medical care. The article presents current trends of dermatology and venereology, approaches to improvement of teaching in medical universities. Department of Dermatology and Venereology of ONMU says that in teaching dermatology, as one of the basic medical sciences, it is necessary to restore an item of interest to students learning the science. The organization of teaching work at the department is focused on the ultimate goal of training and professional medical activity.

Вступ. Шкірні та венеричні хвороби дуже різноманітні за своїми клінічними проявами і зустрічаються досить часто [1]. Тому лікарям усіх спеціальностей нерідко доводиться мати справу з такими пацієнтами. До того ж зміни шкіри часто є зовнішнім відображенням захворювань внутрішніх органів, центральної нервової системи або тяжких системних захворювань. Знання основ дерматології розширює професійний кругозір будь-якого лікаря-клініциста, дозволяє йому більш поглиблено обстежити хворого i вибирати оптимальні методи лікування. Дерматовенерологія не $\epsilon$ “вузькою” спеціальністю, володіти якою повинні лише фахівці-дерматовенерологи [1]. Навпаки, знання основ спеціальності необхідно в щоденній практицілікарів більшостілікувальних спеціальностей [2]. Саме з цим пов' язана необхідність викладання основ дерматовенерології для студентів майбутніх лікарів-клініцистів.

Основна частина. Засвоєння основ дерматології та венерології дозволить лікарю розпізнавати шкірні

() В. В. Шухтін, О. О. Шандра, А. І. Гоженко та венеричні захворювання, що найбільш часто зустрічаються, надавати необхідну першу допомогу при ургентних ситуаціях, проводити правильні організаційні заходи. Викладання дерматовенерології базується на попередній підготовці студентів на кафедpax медико-біологічного комплексу, а також на кафедрах внутрішніх хвороб і кафедрі загальної хірургії. Отримані раніше знання з нормальної і патологічної анатомії, гістології, нормальної та патологічної фізіології дозволяють студентам освоювати пропедевтику дерматології - висипні елементи і патоморфологію шкіри, а також вивчати зміст дисципліни. Знання, отримані студентами на кафедрі дерматовенерології, необхідні для вивчення ряду захворювань інфекційної природи і проведення диференціального діагнозу (кафедра інфекційних хвороб, кафедра акушерства та гінекології, кафедра урологіï) [3]. Знання про системні дерматози (системний червоний вовчак, дерматоміозит, склеродермія, алергічні васкуліти тощо) дозволять освоїти матеріал курсу факультетської та госпітальної терапії [1]. Вивчення основ клініки та 
діагностики інфекцій, що передаються статевим шляхом, формує базис для вивчення відповідних розділів гінекології та урології. Кафедрою дерматології та венерології ОНМедУ проведена робота 3 корекції робочих програм курсу з урахуванням можливості інтегрування 3 іншими кафедрами. Такий підхід до викладання предмета дерматології сприяє більш повному та глибокому засвоєнню навчального матеріалу студентами, дозволяє не тільки повноцінно засвоїти основні положення навчального матеріалу дисципліни, закладені в навчальній програмі, оцінити їх значущість для розуміння питань, що стоять перед практичною медициною, але й направити мислення студентів на глибоке розуміння досліджуваних ними теоретичних і практичних проблем. Інтеграція викладання по вертикалі в нашому предметі допомагає студентам набути наступних знань та вмінь на досить міцній теоретичній основі. Це сприяє розвитку клінічного мислення і застосуваннюзагальнобіологічного підходу до рішення проблем того чи іншого виду патології людини. Нерозривною з інтеграцією викладання в медичному ВНЗ є гуманізація процесу навчання майбутніх лікарів. Ця проблема становить важливу частину діяльності викладачів 3 розробки методологічних проблем медицини, прогнозування розвитку медицини. Це особливо важливо на сучасному етапі, оскільки розвиток медицини вимагає не тільки наявності потужної сучасної матеріальної бази, але й сучасних теоретичних установок, концептуального обгрунтування завдань, які належить вирішувати. У цьому зв'язку нами розглядається на лекціях і практичних заняттях проблема безпосередньої ролі і значення в медицині нашого предмета як об'єкта побудови медичної теорії. Підвищення ефективності процесу навчання досягається також шляхом максимальної диференціації та індивідуалізації навчання стосовно цілей підготовки кожного майбутнього фахівця, його можливостей і ступеня вихідного рівня знань і т. Д., доцільність і значимість такої індивідуалізації та диференціації навчання визнавалися і здійснювалися завжди, але робилося це несистематично і нецілеспрямовано [4]. Мета диференціації навчання зводиться до: досягнення студентами, що

\section{Списоклітератури}

1. Дерматовенерология / В. В. Чеботарев,О. Б. Тамразова, Н. В. Чеботарева, А. В. Одинец // Учебник.-2013.-С. 15-21.

2. Коваленко О. С. Проблеми методичної підготовки викладачів спеціальних дисциплін / О. Є. Коваленко // Педагогіка і психологія. - 1996. - № 4 .

3. Волосовець О. П. Питання якості освіти у контексті впровадження засад Болонської декларації у вищій медичній мають різний вихідний рівень знань і умінь, однакового вихідного рівня знань, умінь і навичок; засвоєння студентами, що мають однаковий вихідний рівень підготовки знань з різних питань дисциплін і вміння використовувати їх для аналізу ситуаційних задач. Ще однією з форм самостійної роботи студентів є участь у наукових розробках кафедри з подальшим написанням наукових робіт і виступів на студентських наукових конференціях.

Одним з факторів, що забезпечують підвищення якості викладання і формування загальноєвропейської системи вищої освіти, є впровадження рейтингової системи оцінки знань студентів. Галузева науковометодологічна лабораторія ОНМедУ розробила систему оцінювання навчальної діяльності, яка проста для викладача, прозора для студента, наближає освіту до європейського рівня, активізує самостійну роботу студентів. Зокрема, оцінювання поточної успішності складається з оцінювання самостійної роботи, а також участі в обговоренні результатів, їх аналізі, корекції та рішенні тестових завдань. Це сприяє підвищенню мотивації студентів до самостійної роботи над навчальним та лекційним матеріалом з метою набуття знань, необхідних для професійної діяльності.

Висновки: 1. Удосконалення викладання дерматології та венерології має на меті підвищення конкурентоспроможності всієї медичної освіти на основі підвищення іiї якості, базисом для цього є матеріальнотехнічне забезпечення, що з успіхом використовується в розвинених країнах Свропи та залишає бажати кращого в нашій країні.

2. Кафедра дерматології та венерології шукає шляхи поліпшення своєї матеріально-технічної бази за допомогою спонсорів, використовує дані клінічних лабораторій, самостійно купує інструментарій, хімічні реактиви та канцелярські товари, видає методичні вказівки до всіх трьох модулів предмета українською, російською (для російськомовних) та англійською (для англомовних студентів) мовами.

3. Підвищення якості викладання безпосередньо пов'язане з досить відповідальним підбором кваліфікованого викладацького складу.

школі / О. П. Волосовець // Медична освіта. -2005. - № 2. C.12-16.

4. Суліма $€$. Невідкладні завдання системи вищої освіти на новому етапі Болонського процесу / С. Суліма // Вища школа. -2010. - № 1. - С. 5-13.

Отримано 06.02.15 